\title{
History in Popular Magazines: Negotiating Masculinities, the Low of the Popular and the High of History
}

\author{
By Bodil Axelsson
}

\begin{abstract}
This article explores how the low of the popular and the high of history intersect to negotiate masculinities in the nexus of politics and war in a Swedish history magazine. It investigates the content of the magazine's form and argues that it produces a kaleidoscopic take on the past which begs the reader to go along with the ads to buy another book, travel to one more historical site, buy a DVD or go to the movies, to turn the page, or to buy another issue of the magazine. Two articles, biographical in their outset, provide the basis for an analysis on how masculinities are negotiated by displaying political and military leaders in contradictory ways and enabling multiple entrance points for the contemporary reader and spectator. Articles on great men produce cultural imaginaries of warlords and political leaders by drawing on layers of historically contingent ways for men to act in public and private spheres and connecting late modern visual celebrity culture to the cults of fame in earlier centuries.
\end{abstract}

Keywords: History magazines, popular culture, popular history, masculinities, cultural imaginaries, celebrity culture, the content of the form. 


\section{History in Popular Magazines: Negotiating Masculinities, the Low of the Popular and the High of History}

Celebrities, stylish interior designs, glamorous women, laddish men, brand new technology, scientific discoveries, and exotic places. These days, well-stocked newsagents proudly display a plethora of glossy magazines. Digital technology has made magazines relatively inexpensive to print and ready-to-use generic formats are easy to copy. The glossy, thick paper of magazines suits images well and offers consumers as well as advertisers a sense of luxury (Alström \& Hedman 2008). In Sweden alone, six hundred new titles were launched between 1995 and 2005 (Antoni 2007: 105).

This article deals with one segment of the magazine market, history magazines, and more specifically only one of the magazines available on this particular topic. Launched in 1991, Populär Historia, soon became the flagship of a mini media empire dependent on history for its primary subject matter. At its peak, the media company included two publishing houses, an Internet shop for books, DVDs, collaboration with a travel company and four magazines. Over the course of time, several new titles on the subject matter of history entered the newsagent's shelves, and Populär Historia was singled out as the qualitative and educational alternative to historical magazines with more popular addresses. Before Populär Historia was sold off to a competing company, its owners launched three new titles, one with an even more popular address, and two specialized in military history and biography respectively, giving evidence to the notion of an increasingly fractured and differentiated magazine market, on which new titles tend to address smaller and smaller segments of topics, audiences and advertisers (Sundin 2009: 11).

In this article, two biographies of great leaders will provide the base for an exploration of how the nexus of masculinity, power and war is negotiated in Populär Historia. This nexus is at the heart of the magazine's representation of the past (Sjöland 2011: 61ff). Here it is embedded in a discussion on the effect of the medium, how the soberness of the subject matter of academic history is negotiated. A magazine is visual in its appearance and its form links to leisure. It encourages browsing and spectatorship. It is glossy and associates to a spectacular popular culture in which different genres and titles address different communities of consumption based on social formations such as gender, class and generation. Like popular culture in general, magazines negotiate situated and contingent scripts for femininity and masculinity (Hermes 2005; Melman 2006).

This article follows in the footstep of those cultural studies and media scholars who have cast magazines as sites for the construction and negotiation of femininities and masculinities in relation to practices of consumption (Winship 1987; McCracken 1992; Hermes 1995; Nixon 1997; Jackson, Stevenson \& Brooks 2001; Benwell 2003; Crewe 2003). Even though postmodern and poststructuralist theory and practice have destabilised and deconstructed binary oppositions such 
as masculinity/femininity, public/private, reason/emotion, and high/low, this article will argue that these pairs are still useful for understanding the ways in which masculinities are negotiated in Populär Historia. Masculinities are, in this article, approached as social and cultural constructions manifest in discursive and material forms as well as in the lived experiences of actual people. This article especially regards masculinities in relation to those interlinking images, motifs and narrative themes that make up cultural imaginaries. Cultural imaginaries here refer to public forms shaping the fantasies of real men and women (Dawson 1994). The approach seeks to recognise the differences within genders as well as in the possible constructions of masculinities, and femininities. It recognises that masculinities and femininities are conceptualised as a set of ideal types, realised in enactments of actual men and women (Paechter 2006). These ideal types are expressed in cultural imaginaries given material form in, for example, print media (Dawson 1994). Furthermore, the approach strives to acknowledge the potential contradictions in the nexus of masculinities, power and war, recognizing layerings and complexities, thus incorporating recent reformulations of the theory on hegemonic masculinities (Connell 1995; Connell \& Messerschmidt 2005; Seidler Jeleniewski 2007).

\section{The Effect of the Medium}

This essay is based upon a close reading of two articles in Popular Historia's annual volume from 2007. These articles contain within them aspects that are common in many other articles with similar topics that the journal has published over the years. The reading of the articles is embedded in an analysis of the ways in which the form of the magazine implies a culturalisation of the subject matter of history. The notion of culturalisation directs attention to the ways in which aesthetics, entertainment, media and fiction pervade more and more societal sectors and practices. Often, the result is blurred distinctions between previously separated areas (Fornäs et al. 2007a).

The exploration undertaken in this article on the culturalisation of history relies upon a browsing and reading of all annual volumes, initially intending for a mapping of themes and narratives in Populär Historia. However, during the course of the analysis I was somehow overpowered by the sheer amount of stories and images and instead decided to allow this impression of mine to be the starting point for an exploration into the format and how it affects the subject matter of history. This move causes this article to sidestep one of the most significant analytical traits in studies in the uses of history. It does consider the magazine's narratives, but does not aim at a systematic overview. Narratives have, in recent decades, turned into the preferred analytical tool in studies on historical representation and how humans relate to past times (Ricœur 1984; 1985; 1988; White 1987; Aronsson 2004; Rüsen 2004). As suggested by Hayden White, the meaning of a nar- 
rative lies as much in its given discursive form, as in its subject matter. How the past is presented, matters as much as the course of events being presented (White 1987). This article takes the 'content of the form' thesis of Hayden White beyond narrative tropes in order to take a sweeping approach to how history is given expressive and material form in one particular media form, the magazine. It will be argued that magazines produce an impression of a multitude of narratives, presenting the past as through a kaleidoscope. It is the implications of the kaleidoscope that interest me rather than a mapping of the narratives.

\section{Tailoring the Magazine for a Specific Set of Readers}

The format has an impact on how the past is displayed in magazines. It also impacts the reception of the magazine and what knowledge the media company sets out to acquire about potential readers. Knowledge about audiences is crucial to the success of media companies and statics are an important tool to produce that knowledge (Ang 1996). According to figures from Orvesto, a company dedicated to market surveys, Populär Historia had 60-80 percent male readers in 2007. Their readers are evenly spread in the ages between 15 and 79 (ORVESTO Konsument 2007). All in all, they had an audience that was comprised of around 150000 readers (Bergsten 2007).

More specific information on Populär Historia's readers is presented in a brochure selling the readers to advertisers. Here it is stated that Populär Historia covers a variety of topics in order to allure a large group of highly educated, curious and influential people. The readers have leading positions in the private, as well as the public sector, and are often active in voluntary associations. The brochure continues: the magazine is available in libraries, trains, airports, and in the waitingrooms of medical doctors and at hairdressers. Here it is stated that the readers are evenly distributed between the ages of 25 and 64, and sixty percent are male. The target group has a university education and the majority live in households with substantial incomes (Annonsinformation 2009).

One can clearly see that it is the affluent and educated middle class that constitutes the prime target readers. The young readers, who might read the magazine in their history lessons at school as well as retired people, are excluded. Instead, the focus is on men with careers and money to spend. It is inferred that the magazine is used to pass time while waiting for an appointment or on a journey. By not explicitly mentioning their female readers, the brochure connects to discourses linking male bodies and masculinities to the subject matter of history. The connection between, on the one hand, male audiences and, on the other hand, military and political history seems to be particularly strong (Rosenzweig \& Thelen 1998: 30, 264; Ludvigsson 2003: 80; Jordanova 2006: 176).

In an article from a Swedish newspaper some years ago, Populär Historia's chief editor and the head of the publishing house jointly stated that they created 
the magazine for people like themselves, a general public with an interest in history. They constituted their own target audience and made use of their experiences from business journalism and museum photography respectively. Addressing a recurrent critique of the magazine for being conspicuously male in its outset, focusing on kings and war, Erik Oswalds and Björn Andersson state that they strive to accomplish a balance in their choice of topics (Rubin 1999).

A similar rhetoric returns almost ten years later when the publishing house gave an interview on another of its magazines, Allt om Historia:

\footnotetext{
- we are trying to provide a mix that attracts both men and women, and those that have a special interest in history as well as those that one day may buy Allt om Historia, and the next buy Fiskejournalen or Amelia, explains Åke Persson, editor of Allt om Historia. There is no magic formula, but we are aiming at a mixture of the soft and the hard. - And, there has to be a war. (Chukri 2004; author's translation)
}

This citation situates the magazine in relation to other magazines currently for sale and casts the history magazine as an option amongst other magazines. The consumer might as well buy a magazine dedicated to fishing, a masculine coded leisure interest, or a lifestyle magazine targeted at women. It displays how the producers implicitly rely on a gender division when targeting their magazine's audience. Men and women are supposed to have different interests. Drawing on stereotyped ideals of femininity and masculinity, it is suggested that their interests might be conceptualized as soft and hard respectively. The citation also suggests that the producers are actively trying to deal with the critique of their products being too masculine in their outset, at the same time as they surrender to what they comprehend as a demand for articles on wars. Finally, the citation points to a paradox produced by an increasingly competitive market for popular magazines. The scope of popular magazines has to be at once broad and particular, attracting as many as possible to take interest in a special interest area (Hirdman 2001).

\section{History in Popular Culture}

The history magazine is one of many contemporary media formats that accentuate the ways in which consumption practices shape how the past is represented (de Groot 2009; Sjöland 2011). The subject matter of history is often associated with the written word and institutions such as the university, schools and education in public service media or popular movements. However, there is also a long trajectory of what Maurice Samuels labels as a 'spectularization of the historical imagination', that is representations of the past dominated by conspicuously commodified images (Samuels 2004: 17). In her book on the culture of history in England 1800-1953, Billie Melman calls attention to a paradox of the period she studies; increased literacy was paralleled by an expansion of visual media such as exhibitions, dioramas, panopticons, theatre and opera performances, and later film (Melman 2006: 318). As we will see, this paradox is still alive. 
Today, critics would say that history is on the verge of being consumed by popular culture. University trained historians are not the only ones to claim expertise (Winter 2006: 6; Aronsson 2011: 20). Journalists and amateurs write history and their audiences are heterogeneous (Jordanova 2006: 134-135; de Groot 2009). Addressing the issue of popular history, Ludmila Jordanova suggests it is history designed to attract many people and that it is included in the broader and more diverse phenomena of public history. Public history accentuates that the past is open-ended and available for a number of uses (Jordanova 2006: 126-136).

The recent wave of history in popular culture cannot be separated from what Jay Winter labels the twentieth-century 'memory boom'. The ubiquitous use of the past is almost over-determined in the sense that no single decisive cause can be decided. Historical remembrance is nurtured by many broad political and economic trends. In the context of this article, the development of broad strata of affluent and well-educated people is especially poignant, since Populär Historia address audiences within these segments. One of the most significant factors, pointed out by Winter however, is the commemorations of the two world wars. A vast number of people were personally involved in, or have relatives affected by, the wars. The lived memories of the wars entangle with commemorations as well as with history and media representations (Winter 2006).

In his mapping of history in contemporary popular culture, Jerome de Groot (2009) reports on a multiple, multiplying and unstable set of representational practices and sensory activities in a wide span of media formats, from celebrity historians in print and broadcast media, to documentaries, costume dramas, reenactments, genealogy, digital archives and community websites. Following in the footsteps of cultural studies and new media research, de Groot emphasis digital media's interactivity. He thus casts the consumer as involved, connected and productive and he points to the interplay between commodity culture and educational leisure activities. This move enables him to sidestep the century long debate on whether popular culture pacifies its audiences or not and it places him in the circle of 'cultural populists', celebrating popular culture (McGuigan 1992).

History in popular culture has had its share of critics, standing in the opposite corner of de Groot. There are plenty of professional historians who are concerned about the lack of cognitive and scholarly value in history shaped for mass audiences and produced with the interest of profit (Ludvigsson 2003, forthcoming). Roy Rosenzweig (2006: 140-144), embracing popular uses of the past himself, has directed attention to the ways in which amateur and popular history take interest in vivid details, facts and personal interest stories rather than the broader pictures. Simon Schama, also a proponent of visual history has pointed to the ways in which television history, spectacular and colourful rather than sober and textbased, trouble academic historians (Schama 2004).

The possibility of outlining the two positions of the embracer and the critic connects history in popular culture to the high/low divide in culture. The popular 
has, for a long time, been associated with mass media, consumer culture, and inferior cultural products appreciated by many people. In some instances popular culture refers to the (traditional) culture of the common people (Storey 1993). Another influential approach to popular culture connects it to a struggle over hegemony in everyday life (Fiske 1989).

The term popular history often connects to the definition of popular culture as mass mediated and commercial culture, and the Wikipedia entry on the term underlines that its meaning is defined in contrast to academic history (http://en.wikipedia.org/wiki/Popular_history, last accessed 2011.09.21). History, without the epithet popular, on the other hand, refers, in its widest sense, to events in the past and how they are given expressive and material form. As accentuated above, the practices in which history is studied is strongly associated to institutions with educational aims such as universities (Eriksen 1999: 13; Jordanova 2006: 13; Edquist 2009: 18). Approaching history on a conceptual level, Peter Aronsson suggests that history might be defined as an arena for negotiations on the what, and why of the subject matter, for which audiences and with what aims. The fact that the past cannot be re-lived, but has to be re-told, opens up a space for the consideration of representations, as do the strong connections between the writing of history and claims to power (Aronsson 2011). In Sweden, negotiations around popular forms of history have a background in twentieth century discourses within circles of popular education. Voices here were raised against the dry and sombre tone in academic history. Modes of addresses from fiction, such as the thrill of a good story, empathy and intuition were presented as positive antidotes to academic history (Edquist 2009: 69-71, 186). And conversely, academics take interest in establishing borders to popular history books and historical novels (Ludvigsson forthcoming). The following paragraphs will connect these negotiations to the gendering of popular culture and academic history in the nineteenth century when the low of the popular and the high of history was established.

\section{The Gendering of Popular Culture and History}

According to a modernist outset, no longer in place in its entirety, but part of an implicit, naturalised consensus, popular culture is associated to the domain of the feminine (Hermes 2005: 137). In the field of literature, this modernist chain of signification associated feminine reading habits with mass-culture, emotion, and consumption, whereas masculine reading habits were linked to high literature, intellectual activity and the production of knowledge (Huyssen 1986: 49-59; Modleski 1986 (2005): 48-49; Hermes 2005: 136-37).

The gender binary and its associated discursive chain of signification were also influential in the production and consumption of history during the nineteenth century. Bonnie G. Smith (1998) suggests that even though academic history firmly placed itself in the domain of the universal, positioning the historian out- 
side the male/female dichotomy, the scientific rationality was implicitly coded masculine. The division was discursive as well as material, very few women were allowed in the seminar rooms to debate archival sources and test arguments. The gender division within the developing practices of history connected to the wellknown nineteenth century association between masculinity and the public sphere and the femininity of the private. The masculine coded subject matters of political history, the history of states, its rulers, governments and relations, dominated the early discipline of history. Smith (1998) contrasts this professional strand of history to 'high amateurism'. The high amateurs were women writing cultural history on the material culture of the everyday life covering a wide societal spectrum, from prominent queens and noblewomen to local history and working class women. They wrote novels, reportages, essays and political critique. According to Smith (1998: 170-171), 'the amateur expanded cognition to include aesthetic, emotional, and kinetic registers' and their products often contained 'detailed descriptions of women's fancy work, furniture, sculpture, jewellery, and other works of art, increasingly their books carried many pictures'. Like in the genre of romantic historicism, the texts became spectacular through the use of panoramic descriptions materialising settings before the mirror of the mind (Smith 1998: 159; Samuels 2004: 15; Melman 2006: 66pp).

The feminine coded 'high amateurism' coincided with the late nineteenthcentury development of feuilleton novels and popular magazines (Smith 1998: 159-160), that is, media forms discursively linked to femininity and consumption. But it was not only women that were positioned as consumers when general interest magazines developed in North America. General interest magazines showed the middle-class in its entirety how to join consumption and education (Schneirov 1994; Ohman 1996; Sharpe 2000; Rothenberg 2007). Even so, development in the US was discussed in terms of feminization, leading to efforts to reinvent manhood via sporting activities (Kimmel 1993/2003).

Cultural studies and media scholars have, in their work on the advancement of men's magazines in the UK in the late twentieth century, addressed a very similar development. Here, a set of new magazines spread in concert with innovations in men's wear design and advertising, producing a new visual coding of masculinity (Nixon 1997). This development may be interpreted 'as a reaction of (and as an active force in shaping) men's changing gender relations and identities' (Jackson, Stevenson \& Brooks 2001: 2). In the eighties, magazines presented men as objects to be looked at and supported ideals of bodily care, consumption and leisure. Their followers in the nineties displayed ideals and ambiguities related to sexuality, drinks and football (see also Benwell 2003). Magazines are thus prisms for the negotiating of different masculinities (Jackson, Stevenson \& Brooks 2001). Before heading into the negotiations of masculinities in Populär Historia, I will delve upon the ways in which this magazine connects the subject matter of history to the domain of consumer capitalism. 


\section{Promoting the Consumption of History}

Populär Historia resembles magazines addressing a female readership in the ways it reworks its subject matter in one issue after the other. If magazines addressing women cultivate femininities associated to beauty and fashion (Winship 1987; Hermes 1995, Lövgren 2009), Popular Historia nurtures readers who have a serious interest in learning more about the past, especially the history of the Swedish nation, cultural history, western military history and the biographies of celebrity politicians, kings, warlords, queens and noble women, explorers and archaeologists. Correspondently to women's magazines, there is a continuum between editorial material and advertisements linking the subject matter of the magazine to the consumption of related goods (McCracken 1993). In the case of history magazines, the preferred links are made to popular history books (de Groot 2009). But as I will develop upon below, Populär Historia draws together a wide range of goods in different genres and media dealing with history in a broad sense.

Populär Historia is a case in point of a generic thematic correspondence between editorial content and ads. Often, the correspondence takes on the form of manifest intertextuality. Articles deal with the topics of books advertised in the same, or close in time, issues. The magazine's review section further enhances the links to the book market even though the correspondence between the review session and the ads is not as strong as the link between ads and articles. Looking at the chronology of Populär Historia's publishing house, it turns out that the magazine predated its book branch. It was the magazine and the contacts with the authors that prompted the publishers to start publish popular history books (Rubin 1999).

The success of Populär Historia developed in concert with an increasing sale of books in book clubs and Internet shops (cf Bohlund 2008). Populär Historia displays ads from a wide range of publishing houses and several Internet bookshops extending, by far, their own publishing house. Editorial sections also present new movies, museum exhibitions, and promote travel destinations of historical interest, at the same time as film clubs, museums and travel agencies are frequent advertisers. Some ads are presented on pages designed so as to create an impression of an editorial selection. Each issue contains several pages drawing together smaller ads from travel agents and book clubs, museum's home pages or antiquarian bookshops under common headings such as Historic sites, Historic Links or the Historic Store-House.

Populär Historia demonstrates plenty of editorial 'tie-ins' providing associative links and thematic overlaps between articles and ads (McCracken 1993: 45). For instance, a review of a book on the history of ideas within Christianity is illustrated by an image of St Peter's Basilica in Rome. The following page displays a different image of the same building, in the context of an ad for a book on Rome. Taken together, the two pages might produce an urge for buying books on Rome 
or to read up on the subject. A more obvious case is the when two ads for journeys to Korea are directly followed by an article on the Korean War. In both examples, adjacency and placement boost the messages in the ads.

The manifest intertextuality and the thematic overlaps between ads, articles, and various editorial contents, give an impression of a seamless whole. From the point of view of ideological critique, one could argue that the generic form of magazines naturalises ideologies of consumption (McCracken 1993: 42-63). In women's magazines, the content supports the reader's feeling of inadequacy in areas such as beauty, fashion and housekeeping. The editorial content as well as the ads then provide advice and suggest remedies for the perceived need through the consumption of particular products (Winship 1987: 55-64).

When history enters the magazine format, it is coloured by this particular media form's connection to market capitalism. One of the overall logics of market capitalism is to produce a demand for the perpetual production of new and fresh commodities. It seems to be something in the subject matter of history that fits very well with this logic. Ann Rigney (2001) suggests that the writing of history is characterised by imperfectness, produced by the gap between what took place in the past, and how these events can later be represented. The representation of the past is restricted by the lack of information and the vagueness of the topic. Developing on Foucault, Rigney argues that new representations of the past are contingent on existing forms of representations (2001: 93-96).

Rigney's argument supports this article's exploration of the medium's effect on the production of history in Populär Historia. The medium's dependence on images guides the decision on subject matters for articles. Yet another argument of hers, that there is an inherent dissatisfaction, on behalf of authors as well as readers, with existing histories in terms of topics covered, has bearing on one of the claims in this article, that producers and consumers of history in popular culture strive to cover new grounds in order to fill in the gaps of what is available for sale. In her words: 'the perennial failure to capture the past whets the appetite to try again' (Rigney 2001: 139). Rigney's argument applies to cultural history and historic novels, but I will suggest that it is equally relevant to history in popular culture, and more specifically in history magazines. Even though each and every article is a complete entity with a beginning and an end, often with a turning point and a coda, the overall format of magazines begs for the reader to go along with the ads to buy another book, travel to one more historical site, buy a DVD or go to the movies, to turn the page, or to buy another issue of the magazine to learn more about the past and to fill knowledge gaps. 


\section{Kaleidoscoping the Past and Connecting History to the Cult of Fame}

Populär Historia gives the impression of a kaleidoscope, carrying with it an invitation to give it one more turn to find out more about the past. Each and every article creates a temporary entity, produced by a turn of a kaleidoscope. All articles are lavishly illustrated by portraits, paintings of great battles, city panoramas, or eyewitness photography from iconic moments of political or military history. Main articles cover at least two, sometimes up to five spreads. The colourful impression is enhanced by headings printed in colours and the use of coloured backdrops for shorter segments of texts within articles.

Every issue displays a collection of articles, each and every one presents a particular articulation of time and space: a person's life, a particular battle, a war or an aspect of one, an iconic event or series of events, a golden age such as the Swedish Bronze age, the Viking age, or ancient Greece, to mention a few of the cover stories in Populär Historia 2007-2008.

The collected slices of time and space in each and every issue produce a temporary totality constituting an intricate pattern. As there is a new issue every month, the magazine presents a seemingly unfathomable series of space-time slices in new and intriguing patterns. In addition to the cover stories and main articles, Popular Historia contains notices on current jubilees, recent dissertations, archaeological findings in a range of archaeological subdisciplines, iconic photos, shorter articles on objects from museum collections and much more. There is an editorial, pages with letters to the editor, and a review section, all pointing to items recently made publicly available from media companies as well as from public institutions.

Male historians and journalists are the most frequent author's in Populär Historia (Sjöland 2011: 91). The trustworthiness of their articles is generally not carried by references to sources but by the name of the author and his or her title. Titles such as Historians, PhD students and Docents carry with them the expertise in source criticism and knowledge about the past. Journalists and writers have skills in interpreting sources and telling accurate stories. Marianne Sjöland (2011) suggests that Populär Historia presents a modified academic history. It does not reflect contemporary university history in terms of topics covered and even though its stories carry with them explanations of past events they lack critical engagement with sources and explicit models of explanation. Increasingly articles refer to popular history books, movies and television series.

The way in which each and every issue of Populär Historia brings together a vast range of merchandises in the subject domain of history, suggests that it may be compared to a shopping centre, a space, in which a great variety of symbols, texts and images flow through and interplay (Fornäs 2002). On the one hand, it acts as a centripetal force drawing stories and writers toward its centre of rotation. On 
the other hand, the magazine's centripetal force is interlaced with general centrifugal forces, diffusing and multiplying media narratives and authorships, in a range of media and texts.

Such processes of intertextuality and intermediality are intrinsic features of late modern media cultures (Fornäs 2002; Fornäs et al. 2007b). In the domain of history in popular culture, the works of single authorships diffuse into movies, television series, references in biographies, and sites for tourism and play (Aronsson 2004: 131pp, de Groot 2009: 11-13). This type of commercial intertextuality invites readers to follow stories across media spaces and is shaped very differently from the intertextuality practiced by university-trained historians. Academic history is based on critical engagement with publically available sources and sources are used to underpin argument and conclusions (Rigney 2001: 121-122). I would suggest that Populär historia negotiates these two positions.

Visually, the articles resemble bricolages, with the re-use of images from a range of different genres and techniques. What are produced here are simulacra, spectacles and stereotypes without any references to originals in the wake of the cultural logic of late capitalism (cf. Jameson 1991). Preferably the magazine uses images to visualise the facts of the captions or to highlight details in the articles. Even though they often take up more space than the text, the images are most often displayed without any critical reflection on their contexts of production. Instead, the images are stamped with references to the image agency that 'owns' the image and who are specialized in circulating images for endless digital and commercial reproduction. The named authors, and the connections made to academic history, provide the magazine with legitimacy, something that its glossy materiality and spectacular design cannot achieve.

Some of the most shimmering pieces in Populär Historia's kaleidoscope display the lives of royalty, noble men and women, political leaders, militaries or warlords, artists, scientists and explorers. The magazine's focus on biographies and its visual format connects Populär Historia to popular culture's cult of celebrity. The notion of celebrity is sometimes traced back to depictions of political leaders on coins, statues and other imageries produced already by the Romans (Braudy 1986; Gamson 1994: 17; Barry 2008: 253). It boomed much later in panopticons in which villains; sovereigns; vaudeville stars; explorers and literate men were put on display (Barry 2008). Later technological and organisational developments, supporting the circulation of text and images in print and the movies, were important forerunners to current celebrity cults in television, gossip magazines and on the web (Barry 2008; Nyblom 2008). Here Madame Tussaud's waxworks museum makes up a connection between not only the earlier century's cults of fame and contemporary times fads for celebrity, as suggested by (Barry 2008), but also the interrelations between fame, celebrity and what Billie Melman (2006) labels as the 'culture of history'. Today, the link between halls of fame, celebrity culture and history in popular culture is reinforced by the popularity of the bio- 
graphical genre. The way in which the genre of the biography 'contains a life, attempts to explain, account for and map it out' (de Groot 2009: 38), seems to make it extremely suitable for books as well as articles in history magazines. Below, I want to focus on two articles, biographical from the outset, in which the nexus of masculinities, power and war is negotiated by the use of images and generic traits from celebrity journalism.

\section{Victories and Losses of Peter the Great}

Populär Historia's biographies of great leaders are peppered with idealizing and deifying portraits. These portraits are public presentations of selves in which accessories acts as props on a theatre stage to reinforce the importance of the sitters (Burke 2001: 26). In addition, coronation dresses and full uniforms produce a sense of grandeur and turn powerful men into icons (Burke 2001: 65-69). The illustrations of an article on the Russian tsar Peter the Great is a case in point (Oredsson 2007). The first article spread paints the picture of an unapproachable and glorious man. The heading, in red, bold letters, presents him as the premiere enemy of the Swedish state. Two thirds of the spread is filled with a portrait depicting him with exceptionally wide shoulders. His masculine appearance is accentuated by a fur-trimmed red mantel. A blue ribbon crosses his chest and draws attention to the hand holding on to a sword, indicating that he is ready to defend his country. His mantel is held together by an impressive piece of jewellery and a white elephant, an animal symbolising strength and energy, solidity and memory decorates the blue ribbon. The gaze of the tsar meets the viewer, addressing him or her directly, and demands the viewer to enter into a relationship with him.

Although the portrait of Peter the Great is magnifying, it depicts the tsar in a kind of void, as there are no people around him. It demands the spectator to fill in the void by either identifying with the great leader, becoming his equal, or by stepping into the shoes of his subordinated. The latter subject position is even more accentuated in the two images in the article, which depict Tsar Peter from below. They accentuate that his epithet is the great, and demand the spectator to look up upon the leader. One of these magnifying images is titled the Founding of St Petersburg. It is a reproduction of a work in the genre of history painting and it visualises the facts of the caption, that Peter the Great founded the city in 1703. The painting shows a man in action, surrounded by men whose gazes express either admiration or subordination. This supposedly realistic painting might be contrasted to another reproduction in the article, whose caption highlights that this smallish picture is allegorical. The painting depicts Peter the Great on a horseback against the backdrop of battle. An angel, with a trumpet swans above him; ready to place a victory crown on his head. This is a portrait of Tsar Peter at the battle of Poltava in which the Swedes were defeated and it, as well as the article's other 
battlefield painting, places the spectator outside the actual combats, as a bystander and observer of a victory, rather than a participant in a lost war.

The images in the article thus, in different ways, invite the spectator to admire the emperor. The text partly supports this storyline and the author is Sverker Oredsson, a professor of history who, in 1998, edited a book on the tsar, his Swedish antagonist and their respective peoples. The article in Popular Historia focuses on Peter the Great and starts with his childhood, informing the reader of his upbringing and education. Following a recurrent pattern in Populär Historia, the childhood, together with a few decisive moments, are presented as formative for how his life developed. The success story focuses on how the Russian army defeated the Swedish armed forces and conquered Swedish Finland and other then Swedish land areas in the Baltic area. Articles within the article paint a picture of Tsar Peter as a man of reformation, for example by westernising his empire after Swedish models and pushing for women's rights. Another piece of text discusses whether Peter was a genius or a tyrant. The article's coda creates an image of an unusually capable man.

A counterpoint to Peter the Great's achievements is presented in a smallish article within the main article. Here, his life story is told in relation to the women he married or took as mistresses. It is a story about betrayals and cruelty, about how he participated in the beating to death of his son, and how he ended up with drinking problems and a venereal disease. It is illustrated by a history painting, depicting Tsar Peter and his son in what appears to be a domestic environment. The glance into what today appears as private details, behind the scenes, is a common feature of celebrity biographies. It produces a sense of authenticity and intimacy with the otherwise distant star (Dyer 2004: 10). From this point of view, the story of Peter's private life reminds the reader that vulnerability is the flipside of success. It also brings about a kind of masculinity associated to the dark, dangerous and destructive characters in the Romantic Movement (cf Dyer 2004: 11).

The move can also be explained by nationalistic tendencies in the article and a motif from earlier Swedish popular culture of history. It is not the first time that Peter the Great is depicted as a womanizer and a drunkard in the Swedish culture of popular history. Two movies, produced in the 1920s, on the tsar's Swedish counterpart, Karl XII, give a similar portrait of Tsar Peter. In an article on national sentiments and masculinity in these two movies, Tommy Gustafsson suggests that the producers solved the problem, from a nationalistic point of view, of the Swedish defeat by demonizing the Russian tsar and glorifying the Swedish king. Within diverse cultural settings, in particularly those that adhere to Enlightenment rationality and bourgeois values, the excessive life-style associated to Tsar Peter is deemed negative. In the movies, it functions as a counterpoint to the selfcontrolled and sober Swedish king (Gustafsson 2005).

So, whereas the format of the idealising portrait aims at evoking identification, admiration or subordination, the accompanying text open up the possibilities for 
readers to identify themselves with, take pity in, or resent, the not so perfect private person. This glimpse into the domestic life of a powerful man blurs the distinction between, on the one the hand, male bodies, the public sphere and political power, and, on the other hand, female bodies, the private sphere and lack of power. The article on Tsar Peter positions him as considerably less powerful in the private sphere of human relations, than in the public sphere. At the same time, his life story, as it is presented in Populär Historia, gives evidence to the claim that, in his time and place, the private and the public were intricately connected for royalties. It is only with the sharper distinction between public and private spheres, which came with the rise of industrialism, the bourgeois and the middle classes in the nineteenth century, that this distinction really makes sense. The article may thus invite its readers and spectators to look upon Peter the Great with anachronistic spectacles.

\section{Churchill's Melancholy}

A similar, yet different, pattern is repeated in a biography on Winston Churchill (Johansson 2007). His elevated position is accentuated by the heading: 'Born to be a leader'. The first spread shows him in front of his desk, dressed in the power insignias of his time: a black jacket and vest over a white shirt with bowtie. His chest is decorated with a watch chain; his left hand holds a cigar and rests on a map. Here, I particularly want to draw the attention to the map. Maps are a cultural form that link aspirations of territorial power with claims to truth. Somehow paradoxically, they provide solid bases of judgment on the grounds of an informed overview (Rogoff 2000: 75-96). They may serve as vehicles for leaders to make rational decisions as they provide a god's eye view distant from the nittygritty reality of the common soldier.

Popular Historia's feature on Churchill describes a long and power-imbued political career also including quite a few setbacks and disappointments. One of the setbacks, the huge losses at Gallipoli, is highlighted with the reproduction of a painting of the landing at the Anzac Cove. The text underlines that Churchill himself was not the originator of the plan, but he nevertheless took it as a lesson. Otherwise, the article paints a picture of a man who, already as a child, was amused by the adventures of war. Later on, his ambitions were channelled into the fields of literature and politics. The illustrations of the article support this story line, with images of Churchill as a child and as young hussar in the colonies, to photos of his wife accepting the Noble Prize in Stockholm and his funeral procession in London. The photos in between depict Churchill with other political leaders of his time, Chamberlain, Roosevelt and Stalin. Only one image portraits him in relation the ordinary man, inspecting the home guard in London.

The bringing forth of the young Churchill's interest in toy soldiers, his bravery and his first career in the late nineteenth-century colonial wars link his biography 
to the masculinity of the British soldier hero. The figure of soldier hero, writes Graham Dawson, flourishes in popular culture and toys to guide the phantasies and national sentiments of British men. Connected to British imperialism it is, for example, inscribed in the news items and legends of Sir Henry Havelock, who in his time became a 'media star' after his recapture of Cawnpore from Indian rebels in 1857 and his passing away soon after (Dawson 1994: 105).

Churchill's biography in Populär Historia adds another layer to the soldier hero imaginary and invites non-British spectators and readers to buy in to it. Thanks not only to cultural imaginaries and toys, but also to general conscriptions, the military has provided a basis for masculinity as a universal category transcending differences of class and region. Having said this, Dudink and Hagemann (2004) underline that there are substantial differences between the various ways in which men have been integrated and ideologically hailed into political and military projects. There are differences between nations due to differences between military institutions as well as between various types of soldiers depending on rank, occupation and access to power (Wadman 2005).

Churchill's position as a leader of a nation at war is as distant from Populär Historia's ideal middle class male reader as that of Peter the Great. However, Churchill's biography in Populär Historia situates him right at the heart of the key areas in which the power-oriented hegemonic masculinity has been enacted; world politics and the military (Connell 1995/2005: 264). Churchill represents an ideal type of masculinity for all sorts of men to identify with or comply to. In a similar way as with Peter the Great, it is balanced with another type of masculinity. Churchill is associated with the multifaceted and culturally, socially and historically contingent state of melancholy. In some respects, the melancholy makes the elevated leader more human as it portraits Churchill oscillating between two emotional registers, malaise and magnitude, a pendulous motion linked to the black melancholy of creative and intellectual masculinity (Johannisson 2010: 32). The article's first paragraphs paint a picture of a disillusioned leader, blaming himself for not being able to save the British empire. The coda of the article describes the old Churchill as broken and disenchanted with a sense of failure, while at the same time described as the celebrated author of a series of books on WWII and one who had strived to return to political power.

The author of the biography is professor of History Alf W. Johansson, and the biography is followed by a second article written by the journalist Erik Jansson (2007). The second article invites the reader to tour the Chartwell Manor, Churchill's home for many years. Its panoramic description of the surroundings of the house and its interior design resembles genre traits of women's high amateurism (Smith 2000). We have already seen that inserting the private domain into the public sphere is an intrinsic feature of the cults of fame. Following this last line of thought, one could argue that Churchill staged his home for public use. Already in Churchill's lifetime, the estate was sold to National Trust, a charity organization 
which protects and opens heritage buildings to the public. Like so many other homes of writers, artists and politicians, Chartwell was turned into a monument of its owner meant to remind future generations of his accomplishments. The article's giving away of dark details on the lives of Churchill's children casts shadows on the elevated man and points to the genre of the celebrity biography. The article suggests that the Churchill's neglect more or less caused the death of one of their daughters. The parent's deeds are explained away, with reference to the spirit of the time. At the same time, the need for an explanation carries with it a late modern proposition that the reproductive and emotional labour involved in family life, traditionally linked to femininity, is a relevant aspect of masculinity too. However, this is a trace of late modern masculinity that runs counter to the soldier hero masculinity, which is defined in contrast to parenthood and intimacy in the domestic sphere (Dawson1994: 282-283). In this way, this biography too invites the reader and spectator to look into the darker side of the powerful man's private life with contemporary eyes.

\section{Conclusion}

The two biographies discussed in this article have been explored so as to cast light on the nexus of masculinities, power, military and war in Populär Historia. The analysis has highlighted the ways in which idealising portraits, the celebrity cult and layers of historically contingent ways for men to act in public and private spheres intersect in these articles. All in all, the mighty and the powerful are displayed in somehow contradictory ways, enabling multiple entrance points for the contemporary reader and spectator. The biographies start from associating masculinity with power, outlining the ways in which these men rule states and empires, how they relate to other leaders, lead armies, fight over territories, found cities and project impressive homes. By giving away details of their domestic lives, the articles underline that powerful men are heterosexual, reproductive and relate to women and children. Yet another preferred masculinity in these portraits is the creative genius touched upon either by excess or by melancholy.

Biographies on leaders, including conflicts between states, are history from above (Jordanova 2006: 42). As a kind of counter position to the magnifying visual imaginary and the success-stories, the printed words in the articles present the extremely powerful as weak in domestic life. Drawing on masculinity ideals associated with the Romantic Movement and pre-modern masculinities, these domestic details unsettle associations of masculinity with reason and femininity with emotion. As a result, the association between masculinity and self-sufficiency is challenged. However, the emotional register of melancholy goes very well with societal power and hegemonic masculinity. Even so, it links the very powerful with the vulnerability of all men and women. It bridges between past and present, between leaders and subordinated or compliant men and women, and secures the 
authority of male political leadership. Masculinities are thus negotiated without profoundly challenging the hegemonic frame.

In the biographies, narratives and images reciprocally provide support to each other. The interdependence pushes the biographies towards reliance of idealising portraits, historical paintings or press photos of iconic events available via image agencies. These images act as a receptacle for a whole variety of fantasies and tie in to cultural imaginaries on warlords and political leadership. The ways in which they detail out insignias and distinguishing outfits sees them also expanding the representations to include material culture as well. Like in the high amateurism, outlined by Smith (1998), the biographies embrace the spectator's aesthetic registers.

Magazines may be conceptualised as a feminine form of media providing spaces for the negotiations of both contemporary and historical masculinities. Especially the visuality of the magazine and its boosting of consumer goods run counter to the educational qualities associated to the male coded political and military history. Populär Historia reworks the subject matter of history in issue after issue while constantly whetting the appetite for new stories drawing on the generic form of the magazine to position both men and women as consumers. Even though the modernist outset that associated femininities with consumption and emotion, and masculinities with intellectual activity and the production of knowledge, has to be considered as superannuated, it somehow casts its shadow over contemporary negotiations on the use of history.

Popular Historia makes biographies into cover stories. The magazine produces a desire for history by connecting late modern visual celebrity culture to the cults of fame in earlier centuries. Idealising portraits send messages of ideal masculinities for spectators to desire and identify with in a similar way as women and men of style and good looks on the covers of women's and men's magazines allure the spectator into a world of consumption associated to specific sets of preferred femininities and masculinities. In Populär Historia, images of powerful men in history hail the reader of historical magazines into the world of rulers, international relations and war also available on the market for popular history books.

However, history magazines such as Populär Historia do more than pack the subject matter of history for consumption. Populär Historia produces a broad address for a narrow audience with the nexus of masculinities, power and war as one of its point of attraction. Its historical representations are equally dependent on the authority of academic history, cultural imaginaries and celebrity cults. On the one hand, by its modified academic history, Populär Historia negotiates the low of the popular with the high of history. On the other hand, in the wake of the contemporary culturalisation of history, the high of history is negotiated when an academic and educational subject matter enters the spectacular world of consumer culture. Populär Historia's kaleidoscopic form contributes to, and is contingent on, what is available in other contemporary media on the subject matter of history. Conse- 
quently, its kaleidoscopic take on the past produces relationships between, on the one hand, publishing houses and various industries that package the past for a consumer market, and on the other hand, real men and women.

Dr. Bodil Axelsson is assistant professor at Tema Q, Linköping University. Her research revolves around history in popular culture, arts based research, museum studies and educational science. bodil.axelsson@liu.se

The author wishes to thank her colleagues at Tema Q, Anna Lundberg at Tema Genus, and David Ludvigsson at the Department of History, Linköping University for comments on ideas and earlier drafts of this paper. The research undertaken for the paper has been financed by the Committee for Educational Science at the Swedish Research Council.

\section{References}

Ang, Ien (1996): Living Room Wars: Rethinking Media Audiences for a Postmodern World, London: Routledge.

Annonsinformation 2009 (2009): Populär Historia.

Antoni, Rudolf (2007): “Tidskrifter”, Ulla Carlsson \& Ulrika Facht (eds): Mediesverige: Statistik och analys, Göteborg: Nordicom Sverige, 105-110.

Alström, Börje \& Love Hedman (2008): "Tidskriftsmarknaden - en rörlig men glömd marknad”, Håkan Hvitfelt \& Gunnar Nygren (eds) På väg mot medievärlden 2020: Journalistik, teknik och marknad, 4th ed Lund: Studentlitteratur, 197-206.

Aronsson, Peter (2004): Historiebruk: att använda det förflutna, Lund: Studentlitteratur.

- (2011): Historia, Malmö: Liber.

Barry, Elizabeth (2008): “Celebrity, Cultural Production and Public Life”, International Journal of Cultural Studies, 11:3, 251-258.

Benwell, Bethan (2003): Masculinity and Men's Lifestyle Magazines, Oxford \& Malden: Blackwell Publishing.

Bergsten, Magnus (2007): “Sveriges mest spännande tidskrift”, Populär Historia, 2007:1, 5.

Bohlund, Kjell (2008): ”Bokmarknadens struktur och utveckling”, Bokmarknaden 2008: rapport från svenska förläggarföreningen,

http://www.forlaggareforeningen.se/media/4433/rapport\%20bokmarknaden\%202008.pdf (accessed 08/12/17), 9-21.

Braudy, Leo (1986): The Frenzy of Renown: Fame and Its Discontents, Oxford: Oxford University Press.

Chukri, Rakel (2008): ”Krig segrar i bokhyllan”, Sydsvenskan 08/08/23, http://www.sydsvenskan.se/samtidigt/article360356/Krig-segrar-i-bokhyllan.html (accessed 09/10/10).

Connell, Raewyn (1995): Masculinities, Cambridge: Polity Press.

Connell, Raewyn \& James Messerschmidt (2005): "Hegemonic Masculinity: Rethinking the Concept”, Gender \& Society, 19:6, 829-859.

Crewe, Ben (2003): Representing Men: Cultural Production and Producers in the Men's Magazine Market, Oxford: Berg.

Dawson, Graham (1994): Soldier Heroes: British Adventure, Empire and the Imagining of Masculinities, London: Routledge. 
Dudink, Stefan \& Karen Hagemann (2004): "Masculinities in Politics and War in the Age of Democratic Revolutions, 1750-1850”, Stefan Dudink, Karen Hagemann \& John Tosh (eds): Masculinities in Politics and War: Gendering Modern History, Manchester: Manchester University Press, 3-21.

Dyer, Richard (2004): Film Stars and Society, 2. Edition. London: Routledge.

Edquist, Samuel (2009): En folklig historia: Historieskrivningen i studieförbund och hembygdsrörelse, Umeå: Boréa.

Eriksen, Anne (1999): Historie, minne og myte, Oslo: Pax Forlag.

Fiske, John (1989): Understanding Popular Culture, Boston: Unwin Hyman.

Fornäs, Johan (2002): "Passages across Thresholds: Into the Borderlands of Mediation”, Convergence: The Journal of Research into New Media Technologies, 8:4, 89-106.

Fornäs, Johan, Peter Aronsson, Karin Becker, Svante Beckman, Erling Bjurström, Tora Friberg, Martin Kylhammar \& Roger QWvarsell (2007a): Culture Unbound: Dimensions of Culturalisation, Report / Department of Culture Studies (Tema Q), 2007:5.

Fornäs, Johan, Karin Becker, Erling Bjurström, Hillevi Ganetz (2007b): Consuming Media: Communication, Shopping, and Everyday life, Oxford: Berg.

Gamson, Joshua (1994): Claims to Fame: Celebrity in Contemporary America, Berkeley: University of California Press.

Groot de, Jerome (2009): Consuming History: Historians and Heritage in Contemporary Society, London: Routledge.

Gustafsson, Tommy (2005): "Nationell ära och manlighet i Karl XII (1925) - en historisk filmanalys”, Scandia 2005, 71:1, 47-76.

Hermes, Joke (1995): Reading Women's Magazines: An Analysis of Everyday Media Use, Cambridge: Polity Press. (2005): Re-reading Popular Culture, Malden, MA: Blackwell.

Hirdman, Anja (2001): Tilltalande bilder: Genus, sexualitet och publiksyn i Veckorevyn och Fib aktuellt, Stockholm: Atlas.

Huyssen, Andreas (1986): “Mass Culture as a Women: Modernism’s Other”, After the Great Divide: Modernism, Mass Culture, Postmodernism, Bloomington: Indiana University Press, 44-62.

Jackson, Peter, Nick Stevenson \& Kate Brooks (2001): Making Sense of Men’s Magazines, Cambridge: Polity Press.

Jameson, Fredric (1991/2001): Postmodernism, or, the Cultural Logic of Late Capitalism, London: Verso.

Jansson, Erik (2007): “Churchills kråkslott”, Populär Historia 2007:1, 32-34.

Johannisson, Karin (2010): Melankoliska rum: Om ångest, leda och sårbarhet i förfluten tid och nutid, Stockholm: Bonnier pocket.

Johansson, Alf W. (2007): ”Född till ledare”, Populär Historia 2007:1, 23-31.

Jordanova, Ludmila (2006): History in Practice, 2. Edition, London: Hodder Arnold.

Kimmel, Michael (1993/2003): "Consuming Manhood: The Feminization of American Culture, and the Recreation of the Male Body, 1832-1920”, Søren Ervø \& Thomas Johansson (eds) Moulding masculinities. Vol. 2, Bending bodies, Aldershot: Ashgate, 2003. 47-76. Originally published Michigan Quarterly Review, Fall 1993.

Ludvigsson, David (2003): The Historian Filmmaker's Dilemma: Historical Documentairies in Sweden in the Era of Häger and Villius, Uppsala: Department of History, Uppsala University.

_ (forthcoming): "Diskuterade motorsågsdocenterna populärhistoria? Historiska föreningen och historikernas relation till populärhistorier”.

Lövgren, Karin (2009): “Se lika ung ut som du känner dig”: Kulturella föreställningar om ålder och åldrande i populärpress för kvinnor över 40, Linköping: Linköping Studies in Art and Science.

McCracken, Ellen (1992): Decoding Women's Magazines: From “Mademoiselle” to “Ms”, London: Macmillan.

McGuigan, Jim (1992): Cultural Populism, London: Routledge.

Melman, Billie (2006): The Culture of History: English Uses of the Past, 1800-1953, Oxford: Oxford University Press.

Modleski, Tania (2005): "Femininity as Mas(s)querade: A Feminist Approach to Mass Culture”, Raiford Guins \& Omayra Zaragoza Cruz (eds) Popular Culture: A Reader, London: Sage, 47-54. 
Nixon, Sean (1997): “Exhibiting Masculinity”, Stuart Hall (ed.): Representation: Cultural Representations and Signifying Practices, London: Sage Publications, 291-336.

Nyblom, Andreas (2008): Ryktbarhetens ansikte: Verner von Heidenstam, medierna och personkulten i sekelskiftets Sverige, Stockholm: Atlantis.

Ohmann, Richard (1996): Selling Culture: Magazines, Markets and Class at the Turn of the Century, London \& New York: Verso.

Oredsson, Sverker (2007): ”Sveriges fiende nummer 1”, Populär Historia 2007:8, 22-33.

ORVESTO® Konsument 2007 Helår (2007): Stockholm: Sifo Research international, http://www.tns-sifo.se/rapporter-undersokningar/senaste-undersokningarna/2009/orvestokonsument-2008helaar (accessed 11/09/09).

Paechter, Carrie (2006): "Masculine Femininities/Feminine Masculinities: Power, Identities and Gender”, Gender and Education, 18:3, 253-63.

Ricoeur, Paul (1984): Time and Narrative, vol. 1, Chicago: University of Chicago Press.

- (1985): Time and Narrative, vol. 2, Chicago: University of Chicago Press.

(1988): Time and Narrative, vol. 3, Chicago: University of Chicago Press.

Rigney, Ann (2001): Imperfect Histories: The Elusive Past and the Legacy of Romantic Historicism, Ithaca, New York: Cornell University Press.

Rogoff, Irit (2000): Terra Infirma: Geography's Visual Culture, London: Routledge.

Rosenzweig, Roy (2006): “Can History Be Open Source? Wikipedia and the Future of the Past”, Journal of American History, Vol. 93:1, 117-146.

Rosenzweig, Roy \& David Thelen (1998): The Presence of the Past: Popular Uses of History in American Life, New York: Columbia University Press.

Rothenberg, Tamar Y. (2007): Presenting America's world. Strategies of Innocence in National Geographic Magazine 1888-1945, Aldershot: Ashgate Publishing.

Rubin, Birgitta (1999): ”Förlag släcker törsten efter vårt förflutna. Historiska Media har stora framgångar i en orolig brytningstid”, Dagens Nyheter 28 June 1999.

Rüsen, Jörn (2004): Berättande och förnuft: Historieteoretiska texter, Göteborg: Daidalos.

Samuels, Maurice (2004): The Spectacular Past: Popular History and the Novel in Nineteenthcentury France, Ithaca: Cornell University Press.

Schama, Simon (2004): “Television and the Trouble of History”, David Cannadine (ed): History and the Media, Houndmills, Basingstoke, Hampshire: Palgrave Macmillan, 20-33.

Schneirov, Matthew (1994): The Dream of a New Social Order: Popular Magazines in America 1893-1914, New York: Columbia University Press.

Seidler Jeleniewski, Victor (2007): “Masculinities, Bodies, and Emotional Life”, Men and Masculinities, 10:1, 9-21

Sjöland, Marianne (2011): Historia i magasin. En studie av tidskriften Populär Historias historieskrivning och av kommersiellt historiebruk, Lund \& Malmö: Forskarskolan i historia och historiedidaktik.

Sharpe, Joanne P. (2002): Condensing the Cold War: Reader's Digest and American Identity, Minneapolis: University of Minnesota Press.

Smith, Bonnie G. (1998): The Gender of History: Men, Women, and Historical Practice, Cambridge, Mass.: Harvard University Press.

Storey, John (1993): An Introductory Guide to Cultural Theory and Popular Culture, New York: Harvester Wheatsheaf.

Sundin, Stefan (2009): Den svenska mediemarknaden 2009, Göteborg: Nordicom, 2009, http://www.nordicom.gu.se/common/publ_pdf/Den_svenska_mediemarknaden_2009_2009061 7.pdf (accessed 11/09/05).

Wadman, Ben (2007):”Military Masculinities”, Michael Flood (ed.): International Encyclopedia of Men and Masculinities, London: Routledge, 441-442.

White, Hayden (1987): The Content of the Form: Narrative Discourse and Historical Representation, Baltimore \& London: John Hopkins University Press.

Winship, Janice (1987): Inside Women's Magazines, London: Pandora.

Winter, Jay (2006): Remembering War: The Great War between Memory and History in the Twentieth Century, New Haven: Yale University Press. 